\title{
ENVIRONMENTAL AND SPATIAL CHARACTERISTICS THAT AFFECT ROOST USE BY SEBA'S SHORT-TAILED BAT (CAROLLIA PERSPICILLATA) IN A COLOMBIAN CAVE
}

\author{
Mónica Peñuela-Salgado*¹ and Jairo Pérez-Torres ${ }^{1}$ \\ ${ }^{1}$ Pontificia Universidad Javeriana, Facultad de Ciencias, Departamento de Biología. Unidad de Ecología y Sistemática \\ (UNESIS). Laboratorio de Ecología Funcional. Bogotá, Colombia.
}

\begin{abstract}
Bats use roost sites to reduce energy costs, for reproduction, and to protect themselves from harsh weather conditions and predators. The roosts differ in the environmental and spatial features that may be used by bats during roost selection, but the relationship between the types of roosts and the physical and spatial characteristics remain poorly understood. We studied the characteristics of roost sites used by Carollia perspicillata in a cave with an area of approximately $600 \mathrm{~m}^{2}$ located in a remnant of tropical dry forest in Colombia.

A total of 156 roost sites were sampled. Temperature, relative humidity, distance of the roost site from the cave entrance, relative location within the cave, the roost-site height, and the roost-site area were correlated with each other by canonical correlation analysis. A total of seven types of roost were identified, Cavity, Protrusion, Crack-withProtrusions, Cavity-with-Protrusions, Cavity-with-Crack-and-Protrusions, Stalactite, and Rock-Structure. Protrusions had the highest frequency (64) and was preferred, along with Crack-with-Protrusions (32), over Rocky-Structure (9) and Stalactite (4), and these were not positively related to the measured characteristics. The Cavity-with-Protrusions, Cavity-with-Crack-and-Protrusions, and Cavity types were not used by Carollia perspicillata. The results indicate that the selection of the roost sites is addressed by the tendency of lower values, environmental characteristics, and spatial measures.
\end{abstract}

\section{INTRODUCTION}

Roost site is one of the most important limiting factors for bats, as they spend more than half their lives in roostbased activities (O'Keefe et al., 2009). Roosting sites may be in caves, mines, rocky crevices, cavities in stems, among leaves, and in human constructions. Bats search for roosts that allow them to protect themselves from climate variations or predators (Fleming et al., 1998) and that also favor their reproduction and increase their survival and that of their offspring (Kurta, 1985; O'Keefe et al., 2009).

The environmental and spatial characteristics of the roosts affect social structure, residence time, energy balance, and intensity of intra- and interspecific relationships (Sedgeley and O'Donnell, 1999). Indeed, environmental characteristics directly affect metabolic rate and energy balance (O'Donnell and Sedgeley, 2006), whereas spatial features can influence parasitism (Altringham, 1988), predation (O'Keefe et al., 2009), competition (Dechman and Kerth, 2008), and the risk of offspring falling from the roost during rearing (Sedgeley, 2001). So understanding the characteristics that bats use during roost-site selection allows an improved understanding of the functional responses to changes in habitat and conditions and their importance in the conservation of bat populations.

Caves are the most common roost sites used by bats (O'Keefe et al., 2009). Several authors have stressed the importance of caves for bat conservation at the regional and local levels (Muñoz-Saba et al., 2007). Caves can shelter numerous bat species whose abundance varies from a few tens to thousands of individuals (Arita, 1993). In temperate zones, many species of insectivorous bats use the caves as permanent roost sites (McCracken and Wilkinson, 2000). In tropical regions, fruit bats frequently roost in caves (Kunz, 1982) such as Olhos d'Água Cave in Brazil and Las Vegas Cave in México, both containing thirteen species, the highest number known (Medellín and López-Forment, 1985; Trajano and Gimenez 1998). Colombia has an extensive system of underground environments of which an estimated 25\% have been mapped (Muñoz-Saba et al., 2007). Seba's short-tailed bat Carollia perspicillata and the common vampire bat Desmodus rotundus are the species most frequently recorded using caves in different regions of the country (Muñoz-Saba et al., 2007), and Macaregua Cave, our study site, is the richest, with ten species found (PérezTorres et al., 2015).

Roosting sites like caves may be selected when they provide a suitable combination of characteristics for roosting (Kunz, 1982; Graham, 1988; Arita, 1996; Aguirre et al., 2003). For some species of bats, roost selection criteria can depend on sex, maturity status, and pregnancy status of females (Sedgeley and O'Donnell, 2004; Willis et al., 2006;

*Corresponding author: penuelam@javeriana.edu.co 


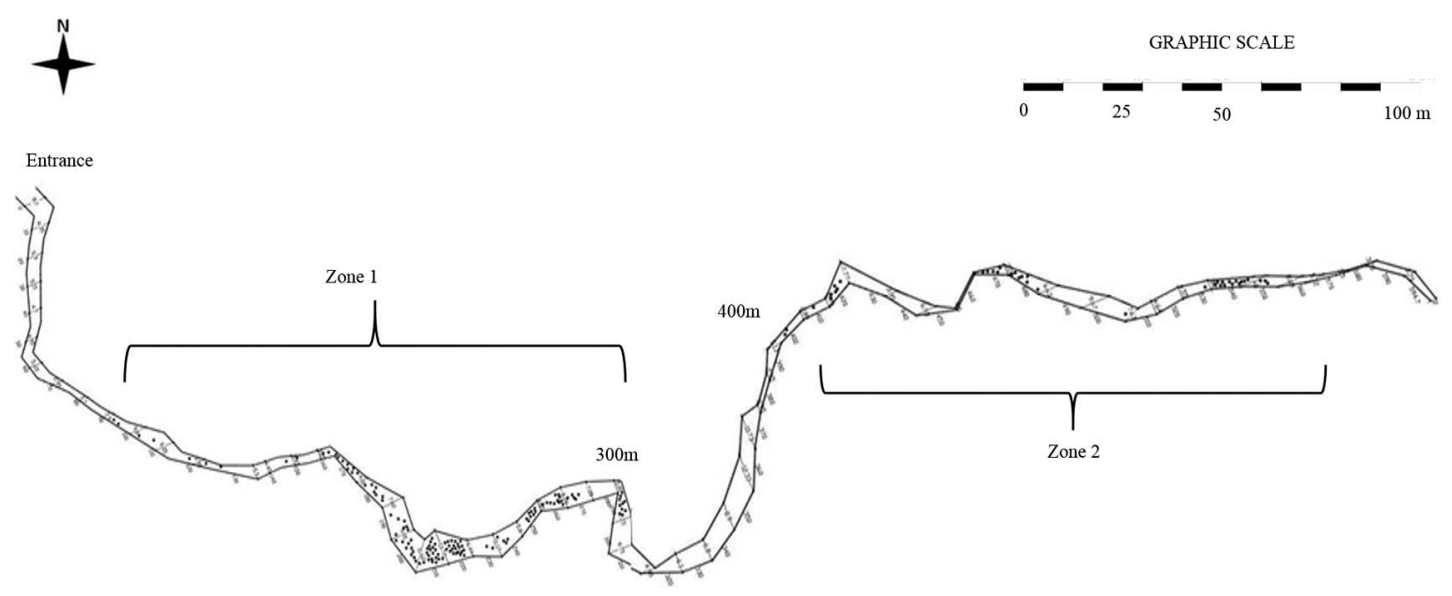

Figure 1. Macaregua cave, Curití, Colombia.

Perry et al., 2007). However, it remains unclear which features are used to select a specific type of roost in underground environments. In this study, we attempt to relate physical (temperature, relative humidity) and spatial characteristics (cave entrance distance, height of the roost, relative location, total area) of roost sites used by Carollia perspicillata with types of roosts present in a karst cave in a tropical dry forest ecosystem in Colombia.

\section{Materials And Methods}

The Macaregua Cave $\left(6^{\circ} 39^{\prime} 36.2^{\prime \prime} \mathrm{N}\right.$ and $\left.73^{\circ} 6^{\prime} 32.3^{\prime \prime} \mathrm{W}\right)$ (Fig. 1) is located in Las Vueltas, Curití municipality, Department of Santander in the northeastern region of Colombia at an elevation of $1566 \mathrm{~m}$. This cave, not altered by man, has two galleries, one dry $(80 \mathrm{~m})$ and one wet (approximately $600 \mathrm{~m}$ ), at least six chambers, and a watercourse for the first $300 \mathrm{~m}$ (Pérez-Torres et al., 2015). The ceiling heights range from 0.22 to $7.3 \mathrm{~m}$, and the passage widths range from 0.6 to $13.72 \mathrm{~m}$. The cave has ancient lithostratigraphic units that appear similar to stalactites, but with a metamorphic-igneous gneiss origin; migmatites, schists, and small granodiorite intrutions are also present (Mejia, 2008).

This study was performed in the dry season, between January 16, 2011 and February 8, 2011, which is the reproductive period of this species of bat. Throughout the parts of the $600 \mathrm{~m}$ of wet gallery used by Carollia perspicillata 156 sites were cataloged. Each roost site was classified according to the structure of the roof of the cave and taking into account the criteria by Unesco and FAO (1972). Roosts were classified into one of seven types, Cavity, Protrusion, Crack-with-Protrusions, Cavity-with-Protrusions, Cavity-with-Crack-and-Protrusions, Stalactite, and Rocky-Structure, the last of which includes those not in any other class, and temperature and humidity measurements were taken at each visit.

At each roost site the roof temperature $\left(62 \pm 1{ }^{\circ} \mathrm{C}\right)$ was measured using a Fluke infrared thermometer 62 with laser pointer, and relative humidity was measured below each roost site using a thermohygrometer Hanna HI 93640 $( \pm 2 \%)$ in both the morning $(0700-1000 \mathrm{~h})$ and afternoon (1500-1800 h); readings were then averaged to produce daily mean values for each type of roost (Table 1). Light was not considered in the study because the cave from $100 \mathrm{~m}$ is in complete darkness.

At each roost site roost distance to the entrance of the cave was measured using a decameter. Relative location of the roost site within the width of the passage, as the distance from the right wall divided by the width, and the height of the roost site from the cave floor were measured directly. The area of the passage at each roost site was estimated by photographic analysis using ImageJ software (Table 1).

Roost types associated with physical location and environmental and spatial characteristics were subjected to canonical correspondence analysis using CANOCO v4.5 (Braak and Smilauer, 2002). Monte Carlo procedures were used to determine if there was a linear relationship between the variables and types of roost (index $p<0.05=\mathrm{Rho}$ ).We evaluated which roost sites were preferred, used, or avoided. For this, the software used was HaviStat v2.2. The program applied several indexes based on the observed frequency and the potential use (area available) of the types of roost found. (Montenegro et al., 2014).

\section{RESUlts}

The average monthly temperature of the cave varies between 23.2 and $27.3{ }^{\circ} \mathrm{C}$, whereas relative humidity varies between 84.5 and $97.2 \%$. Carollia perspicillata individuals are found along the wet passage except between 300 and $400 \mathrm{~m}$ from the cave entrance, which is an area in which insectivorous bats (Mormoops megalophylla and Natalus tumidirostris) roost. This section divides the wet section occupied by $C$. perspicillata into two zones, zone 1 from 100 to 300 meters and zone 2 from 400 to $530 \mathrm{~m}$.

Journal of Cave and Karst Studies, December 2015 • 161 
Environmental and spatial characteristics that affect roost use by Seba's short-tailed bat (Carollia Perspicillata) in a COLOMBian CAVE

Table 1. Types of available roosts in the part of Macaregua Cave where Carollia perspicillata bats roost and average environmental and spacial parameters.

\begin{tabular}{|c|c|c|c|c|c|c|c|c|}
\hline \multirow[b]{2}{*}{ Type of Roost } & \multicolumn{3}{|c|}{ Number } & \multicolumn{2}{|c|}{ Environmental } & \multicolumn{3}{|c|}{ Roost Details } \\
\hline & Total & $\begin{array}{c}\text { Zone } \\
1\end{array}$ & $\begin{array}{c}\text { Zone } \\
2\end{array}$ & $\begin{array}{c}\text { Temperature, } \\
{ }^{\circ} \mathrm{C}\end{array}$ & $\begin{array}{c}\text { Relative } \\
\text { Humidity, \% }\end{array}$ & $\begin{array}{l}\text { Cave Entrance } \\
\text { Distance to } \\
\text { Roost, m }\end{array}$ & $\begin{array}{l}\text { Height of Roost } \\
\text { Above Cave } \\
\text { Floor, } m\end{array}$ & $\begin{array}{l}\text { Cross- } \\
\text { Sectional } \\
\text { Area, } \mathrm{m}^{2}\end{array}$ \\
\hline Protr & 64 & 47 & 17 & $.64 \pm 0.86$ & $.00 \pm 3.63$ & $308.22 \pm 134.19$ & $2.99 \pm 0.63$ & $0.46 \pm 0.19$ \\
\hline $\begin{array}{l}\text { Crack with } \\
\text { Protrusions }\end{array}$ & 32 & 19 & 13 & $5.99 \pm 0.99$ & $3.03 \pm 2.87$ & $338.47 \pm 132.27$ & $3.14 \pm 0.57$ & $0.46 \pm 0.15$ \\
\hline $\begin{array}{l}\text { Cavity with } \\
\text { Protrusions }\end{array}$ & 25 & 19 & 6 & $25.67 \pm 1.18$ & $95.05 \pm 3.62$ & $276.29 \pm 119.23$ & $3.57 \pm 0.59$ & $0.45 \pm 0.20$ \\
\hline $\begin{array}{l}\text { Cavity with } \\
\text { Cracks and } \\
\text { Protrusions }\end{array}$ & 16 & 14 & 2 & $25.57 \pm 0.50$ & $93.08 \pm 0.83$ & $247.33 \pm 87.95$ & $4.01 \pm 0.44$ & $0.36 \pm 0.13$ \\
\hline $\begin{array}{l}\text { Rocky } \\
\text { Structure }\end{array}$ & 9 & 9 & 0 & $24.70 \pm 0.73$ & $88.43 \pm 3.72$ & $200.50 \pm 42.18$ & $2.79 \pm 0.78$ & $0.24 \pm 0.19$ \\
\hline Cavity & 6 & 6 & 0 & $.58 \pm 0.73$ & $88.34 \pm$ & $176.46 \pm$ & $3.30 \pm$ & $0.26 \pm 0.26$ \\
\hline Stalactite & 4 & 4 & 0 & $24.52 \pm 0.82$ & $90.05 \pm 0.82$ & $142.84 \pm 34.99$ & $2.24 \pm 0.29$ & $0.06 \pm 0.02$ \\
\hline
\end{tabular}

Seven types of roost (Fig. 2) were located in those zones of the cave. Between 80 and $300 \mathrm{~m}$ from the cave entrance (zone 1) 118 roost sites were identified, whereas between 400 and $530 \mathrm{~m}$ (zone 2) 38 roost sites were identified. The frequency of different types of roost differed significantly within the cave environment $\left(\chi^{2}=119.2, \mathrm{df}=6, n=156\right.$, $p<0.001)$. Protrusion $(n=64)$ and Crack-with-Protrusions $(n=32)$ were the most frequent types of roost (Table 1). Rock-Structure, Cavity, and Stalactite roost sites were present only in zone 1. Other types of roost were found throughout the cave.

The difference between the temperature data taken in the morning and in the afternoon was not significant ( $W=-1.6 ; n=156 ; p=0.112$ ), but between the morning
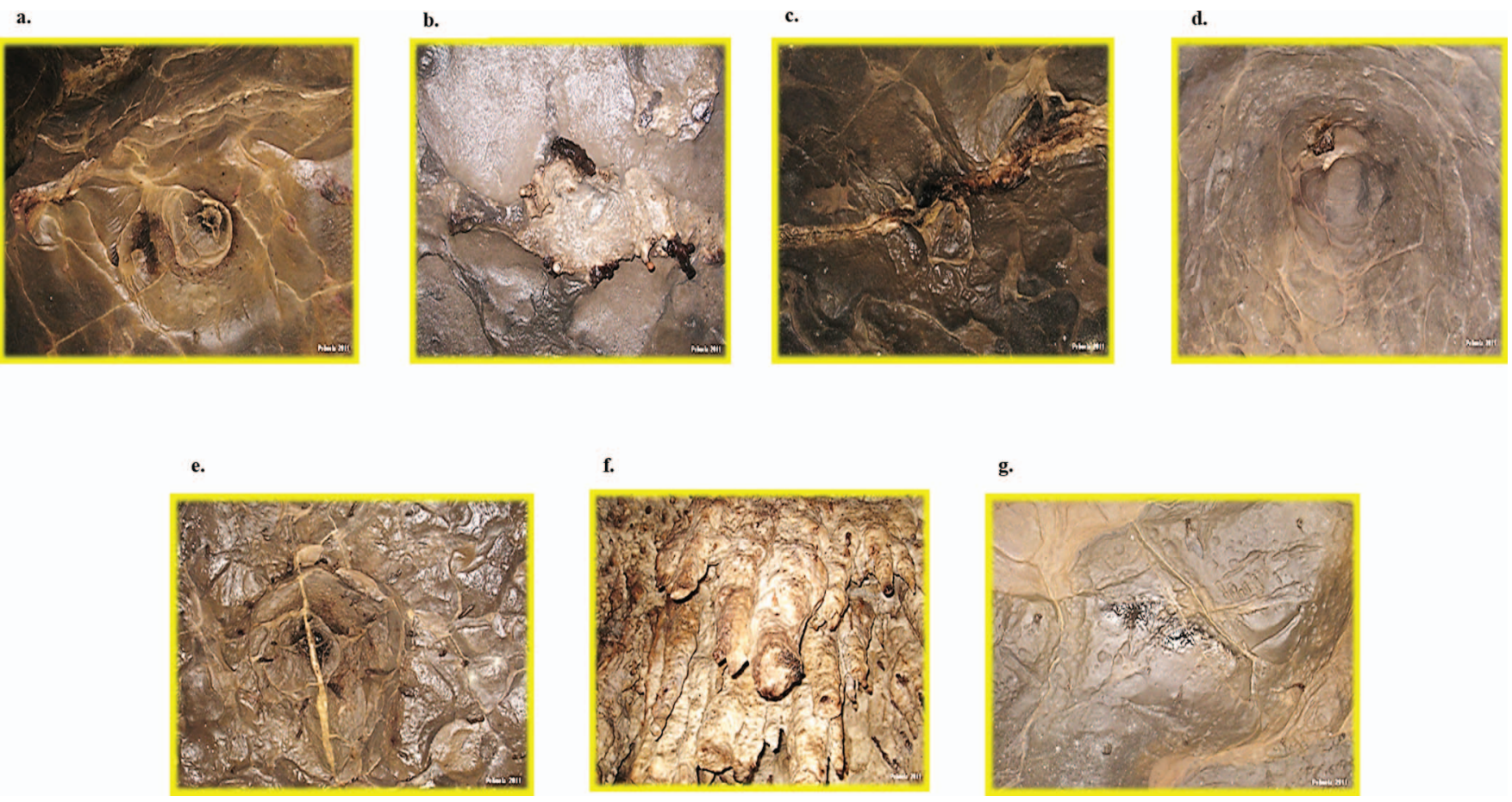

Figure 2. Examples of types of roost found in the cave: a. Cavity; b. Protrusion; c. Crack-with-Protrusion; d. Cavity-withProtrusions; e. Cavity-with-Cracks-and-Protrusions; f. Stalactite; g. Rocky-Structure. 


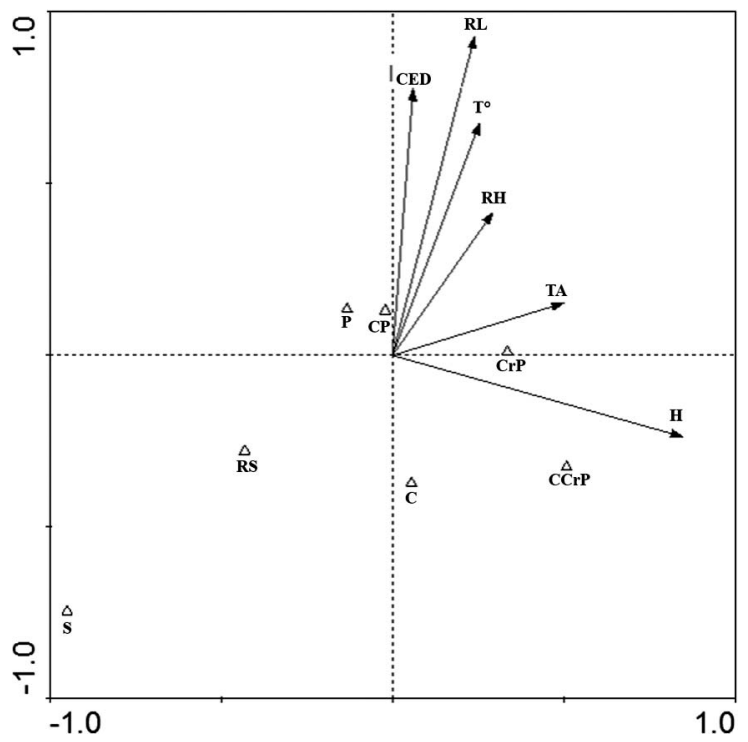

Figure 3. Canonical correlation analysis ordination of the types of roost with environmental and spatial characteristics. Triangles represent the types of roost: Cavity $(C)$, Protrusion (P), Crack-with-Protrusions (CrP), Cavity-with-Protrusions (CP), Cavity-with-Cracks-and-Protrusions (CCrP), Stalactite (S), and Rock structure (RS). Vectors represent the environmental and spatial variables of the roosts: Temperature $\left(\mathrm{T}^{\circ}\right)$, relative humidity (RH), cave entrance distance from roost (CED), height of the roost above the floor $(\mathrm{H})$, relative location (fraction of passage width that is distance from right wall, $\mathrm{RL}$ ), and total passage area (TA) (Table 1). The orientation of the arrow and the size represents the association, direction, and strength between environmental and spatial variables and ordination axes. The first and second axis explains $62 \%$ and $45.3 \%$, respectively, and the total value of the organization itself was 0.768 .

and afternoon relative-humidity data significant differences were found $(W=-3.3 ; n=156 ; p=0.001)$.

Protrusion was the most common type of roost observed (0.41), with Cracks-with-Protrusions next (0.21); RockStructure (0.07) and Stalactite (0.04). Stalactite was the type of roost most used (Manly and Thomas, 1993: $10.6>1$ prefers) and Rock Structure was the second one (Manly and Thomas, 1993: $2.4>$ prefers). The Cavity-with-Protrusions (0.16), Cavity-with-Crack-and-Protrusions (0.11) and Cavity (0.04) were not used by Carollia perspicillata.

Environmental (temperature, relative humidity) and spatial (distance to cave entrance, roost height, roost relative location, available area) variables were associated with the different types of roost (Table 1). Cumulative variance in the types of roost was: axis $1: 50.1 \%$, axis $2: 76.8 \%$, axis 3 : $90.5 \%$, axis $4: 97.3 \%$, respectively (Fig. 3). The large values in the first two axes indicate that the measured variables are significantly explained by the types of roost. The rock structure was inversely related to the measured characteristics, so the roosts with low or medium values are those grouped under that type of roost.

\section{Discussion}

Roost selection by Carollia perspicillata was significantly correlated with temperature and Stalactite was the type of roost site most preferred followed by Rock Structure. Species such as Sturnira lilium, $C$. perspicillata, and Artibeus lituratus select roosts with high altitude in the cave passage (Ortiz -Ramirez et al., 2006). Temperature was a major factor for selection of the types of roost in our study (Table 1), as observed previously (Snoyman and Brown, 2011). In other studies, the temperature is the most important aspect (Vonhof and Barclay, 1996; Fleming et al., 1998; AvilaFlores and Medellin, 2004), and in some others, it is not so important (Ortiz-Ramirez et al., 2006).

Macaregua is a warm cave, and its temperature range ( 23.25 to $27.28^{\circ} \mathrm{C}$ ) coincided with previous findings that indicate that Emballonuridae, Mormoopidae, Phyllostomidae, and Natalidae bat families prefer warm roosting sites (Avila-Flores and Medellin, 2004; Broders and Forbes, 2004). Selection of warmer roosting sites is important because it reduces the need to invest energy resources in bodytemperature homeostasis while sleeping (McNab, 1982).

Spatial characteristics of roost sites can influence heat dissipation and facilitate bat-flight maneuvers in the case of disturbance (Kurta, 1985). The disturbance associated with the entry and exit of the cave (Clark et al., 1996) and the space within the roost site limits the number of bats that use it. Roost structure can also affect social organization (Kunz, 1982) and the formation of groups for thermoregulation (Kurta, 1985), whereas microclimate features of roost sites (Bell et al., 1986) and microstructural heterogeneity favors the establishment of multi-species bat assemblages in caves (Brunet and Medellin, 2001).

Future studies could examine the role of gas concentration on roost site selection, as it is clear that temperature and humidity may vary with changes in the local gas concentrations, particularly the accumulation of ammonia in the atmosphere (McFarlane et al., 1995). This is of particular relevance in caves where changes in the gaseous composition of the atmosphere can correlate with local increases in temperature of $>3{ }^{\circ} \mathrm{C}$ (Baker and Genty, 1998). The role of reproductive status and sex-based differences in roost-site selection are also likely to provide valuable information for promoting bat conservation programs involving cave habitats in the Neotropical region.

\section{CONCLUSION}

Roost selection by Carollia perspicillata involves a combination of physical, spatial, and environmental variables. Stalactite was the type of roost site preferred, and temperature was the major environmental factor. 
ENVIRONMENTAL AND SPATIAL CHARACTERISTICS THAT AFFECT ROOST USE By Seba's SHORT-TAILED BAT (CAROLLIA PERSPICILLATA) in A COLOMBian CAve

\section{ACKNOWLEDGEMENTS}

The Functional Ecology Laboratory (PUJ). Flor Daza and Elías Gómez, owners of Finca La Palma. Luis Alberto Acosta and Trevor Williams for their comments and suggestions on the draft of this manuscript. This study is part of the project Ecology of Bats in Cave Systems in the Department of Santander supported by the Pontificia Universidad Javeriana (ID 5696).

\section{REFERENCES}

Avila-Flores, R., and Medellin, R.A., 2004, Ecological, taxonomic, and physiological correlates of cave use by Mexican bats: Journal of Mammalogy, v. 85 , no. 4, p. 675-687. doi:10.1644/BOS-127.

Aguirre, L.F., Lens, L., and Matthysen, E., 2003, Patterns of roost use by bats in a neotropical savanna: Implications for conservation: Biological Conservation, v. 111, no. 3, p. 435-443. doi:10.1016/S0006-3207(02)003 13-0.

Altringham, J., D., 1998, Bat houses in British forests: Bats, v. 16, no. 1, p. 8-11.

Arita, H.T., 1993, Conservation biology of the cave bats of Mexico: Journal of Mammalogy, v. 74, no. 3, p. 693-702. doi:10.2307/1382291.

Arita, H.T., 1996, The conservation of cave-roosting bats in Yucatan, México: Biological Conservation, v. 76, p. 177-185. doi:10.1016/0006-3207 (95)00105-0.

Braak, C.J.F., ter, and Smilauer, P., 2002, CANOCO Reference Manual and CanoDraw for Windows User's Guide: Software for Canonical Community Ordination (version 4.5): Ithaca, New York, Microcomputer Power, $500 \mathrm{p}$.

Baker, A., and Genty, D., 1998, Environmental pressures on conserving cave speleothems: Effects of changing surface land use and increased cave tourism: Journal of Environmental Management, v. 53, p. 165-175. doi:10.1006/jema.1998.0208.

Bell, G.P., Bartholomew, G.A., and Nagy, K.A., 1986, The roles of energetics, water economy, foraging behavior, and geothermal refugia in the distribution of the bat Macrotus californicus: Journal of Comparative Physiology B, v. 156, p. 441-450. doi:10.1007/BF01101107.

Broders, H.G., and Forbes, G.J., 2004, Interspecific and intersexual variation in roost-site selection of northern long-eared and little brown bats in the Greater Fundy National Park Ecosystem: The Journal of Wildlife Management, v. 68, no. 3, p. 602-610. doi:10.2193/0022-541X (2004)068[0602:IAIVIR]2.0.CO;2.

Brunet, A.K., and Medellin, R.A., 2001, The species-area relationship in bat assemblages of tropical caves: Journal of Mammalogy, v. 82, p. 1114-1122. doi:10.1644/1545-1542(2001)082\%3C1114:TSARIB $\% 3 E 2$. $0 . \mathrm{CO} ; 2$.

Clark, B.K., Clark, B.S., Leslie, D.M., Jr., and Gregory, M.S., 1996, Characteristics of caves used by the endangered Ozark big-eared bat: Wildlife Society Bulletin, v. 24, p. 8-14.

Dechman, D.K.N., and Kerth, G., 2008, My home is your castle: Roost making is sexually selected in the bat Lophostoma silvicolum: Journal of Mammalogy, v. 89, no. 6, p. 1379-1390. doi:10.1644/08-MAMM-S-061.1.

Fleming, T., Nelson, A., and Dalton, V., 1998, Roosting behavior of the lesser long-nosed bat, Leptonycteris curasoae: Journal of Mammalogy, v. 79 , no. 1 , p. $147-155$. doi: $10.2307 / 1382849$.

Graham, G.L., 1988, Interspecific associations among Peruvian bats at diurnal roosts and roost sites: Journal of Mammalogy, v. 69, no. 4, p. 711-720. doi:10.2307/1381626.

Kurta, A., 1985, External insulation available to a non-nesting mammal, the little brown bat (Myotis lucifugus): Comparative Biochemistry and Physiology Part A: Physiology, v. 82, p. 413-420. doi:10.1016/ 0300-9629(85)90876-X.

Kunz, T.H., 1982. Roosting ecology, in Kunz, T.H., ed., Ecology of Bats: New York, Plenum Press, p. 1-55. doi:10.1007/978-1-4613-3421-7_1.

Manly, B.F., McDonald L., and Thomas, D., 1993, Resource Selection by Animals: Statistical Design and Analysis for Field Studies: London, Chapman \& Hall, $177 \mathrm{p}$
McCracken, G.F., and Wilkinson, G.S., 2000, Bat mating systems, in Crichton, E.G., and Krutzsch, P.H., eds., Reproductive Biology of Bats: Sam Diego, Academic Press. p. 321-362.

McFarlane, D.A., Keeler, R.C., and Mizutani, H., 1995, Ammonia volatilization in a Mexican bat cave ecosystem: Biogeochemistry, v. 30, no. 1, p. 1-8. doi:10.1007/BF02181037.

McNab, B.K., 1982, Evolutionary alternatives in the physiological ecology of bats, in Kunz, T.H., ed., Ecology of Bats, p. 151-200. doi:10.1007/ 978-1-4613-3421-7_4.

Medellín, R.A., and López-Forment, W., 1985, Las cuevas: Un recurso compartido: Annales del Instituto de Biología de Universidad Nacional Autónoma de México, Serie Zoología, v. 56, p. 1027-1034.

Mejía, G., 2008, Plan de desarrollo municipio Curití 2008-2011. Development plan, 189 p. http://curiti-santander.gov.co/apc-aa-files/30363033353966 343137363663366231/PLAN_DE_DESARROLLO_CURIT_1.pdf. [accessed October 23, 2014].

Montenegro, J.A., Acosta, A., and Reimer, J.D., 2014, HaviStat@ v2.2: Application to estimate preference for habitat and resources: Universitas Scientiarum, v. 19, no. 3, p. 333-337. doi:10.11144/Javeriana.SC19-3.haea.

Muñoz-Saba, Y., Hoyos-Rodríguez, M.A., and Baptiste, L.G., 2007, ¿Conservación de murciélagos asociados con las cavernas o conservación de las cavernas a través de los murciélagos?: Focus, v. 6, no. 1-2, p. 57-63.

O'Keefe, J.M., Loeb, S.C., Lanham, J.D., and Hill. H.S., Jr., 2009, Macrohabitat factors affect day roost selection by eastern red bats and eastern pipistrelles in the southern Appalachian Mountains, USA: Forest Ecology Management, v. 257, p. 1757-1763. doi:10.1016/ j.foreco.2009.01.037.

O'Donnell, C.F.J., and Sedgeley, J.A., 2006, Causes and consequences of tree-cavity roosting in a temperate bat, Chalinolobus tuberculatus, from New Zealand, in Zubaid, A., McCracken, G.F., and Kunz, T. H., eds., Functional and Evolutionary Ecology of Bats: New York, Oxford University Press, p, 308-321.

Ortiz-Ramírez, D., Lorenzo, C., Naranjo, E., and León-Paniagua, L., 2006, Selección de refugios por tres especies de murciélagos frugívoros (Chiroptera: Phyllostomidae) en la Selva Lacandona, Chiapas, México: Revista Mexicana de Biodiversidad, v. 77, p. 261-270.

Peréz-Torres, J., Martínez-Medina, D., Peñuela-Salgado, M., Ríos-Blanco, M.C., Estrada-Villegas, S., and Martínez-Luque, L., 2015, Macaregua: The cave with the highest bat richness in Colombia: Check List, v.11, no. 2, article 1616, 6 p. doi:10.15560/11.2.1616.

Perry, R.W., Thrill, R.E., and Carter, S.A., 2007, Sex-specific roost selection by adult red bats in a diverse forested landscape: Forest Ecology and Management, v. 253, p. 48-55. doi:10.1016/j.foreco.2007.07.007.

Sedgeley, J.A., 2001, Quality of cavity microclimate as a factor influencing selection of maternity roosts by a tree-dwelling bat, Chalinolobus tuberculatus, in New Zealand: Journal of Applied Ecology, v. 38, p. 425-438. doi:10.1046/j.1365-2664.2001.00607.x.

Sedgeley, J.A., and O'Donnell, C.F.J., 1999, Factors influencing the selection of roost cavities by a temperate rainforest bat (Vespertilionidae: Chalinolobus tuberculatus) in New Zealand: Journal of Zoology, v. 249 , no. 4 , p. 437-446. doi:10.1111/j.1469-7998.1999.tb01213.x.

Sedgeley, J.A., and O'Donnell, C.F.J., 2004. Roost use by long-tailed bats in South Canterbury: Examining predictions of roost site selection in a highly fragmented landscape: New Zealand Journal of Ecology, v. 28, p. $1-18$.

Snoyman, S., and Brown, C., 2011, Microclimate preferences of the greyheaded flying fox (Pteropus poliocephalus) in the Sydney region: Australian Journal of Zoology, v. 59, no. 6, p. 376-383. doi:10.1071/ ZO10062.

Trajano, E., and Gimenez, E.E.A., 1998, Bat community in a cave from eastern Brazil, including a new record of Lionycteris (Phyllostomidae, Glossophaginae): Studies on Neotropical Fauna and Environment, v. 33, no. 2, p. 69-75. doi:10.1076/snfe.33.2.69.2156.

UNESCO and FAO, 1972, Glossary and multilingual equivalents of karst terms. http://unesdoc.unesco.org/images/0000/000019/001976Eb.pdf.

Vonhof, M.J., and Barclay, R.M.R., 1996, Roost-site selection and roosting ecology of forest-dwelling bats in southern British Columbia: Canadian Journal of Zoology, v. 74, p. 1797-1805. doi:10.1139/z96200.

Willis, C.C.R., Voss, C.R., and Brigham, R.M., 2006, Roost selection by forest-living female big brown bats (Eptesicus fuscus): Journal of Mammalogy. v. 87, no. 2, p. 345-350. doi:10.1644/05-MAMM-A-118R1.1. 